\title{
EAP Learners' Perceptions towards the Use of Tasks in Their Books: Focusing on Needs Analysis
}

\author{
Maryam Cheraghi Shehni \\ Department of Language Teaching and Translation, Varamin-Pishva Branch, Islamic Azad University, Varamin, Iran
}

\begin{abstract}
The development of English as a universal language led to the emergence of a new field in English language teaching which is called English for Specific Purposes (ESP). Moreover, English is recently considered as an international language, and with advancements in technology, accordingly, there is a widespread growth in demand for English for Academic Purposes (EAP) courses fluctuating in teaching length and mode. The present study, thus, attempts to consider the EAP Learners' Perceptions towards the use of tasks taught in universities as EAP courses for students and what English skills and abilities are required from them on the job.
\end{abstract}

Index Terms - EAP courses, learner`s perception, needs analysis, task-based language teaching, tasks

\section{INTRODUCTION}

With the development of English in academic communications and the growing demand of university students to involve in disciplinary knowledge through English and later to be capable of functioning successfully in employment, English for Academic Purposes (EAP) has proven itself as one of the two main subdivisions of ESP and developed over the past twenty years rapidly (Hyland, 2006). The term English for Academic Purposes (EAP) is an idea first used by the British Council in 1975 and 1976, the British Council Teaching Division Inspectorate has presented a teaching course in EAP for its English Language teaching staff (Alqahtani, 2011).

As stated by Richards (2001), during the 1960s when English for Specific Purposes (ESP) instruction absorbed the attention of experts, needs investigation started to be employed as a part of the language programs. Then, such a practical term has been characterized and realized by several people differently. Today, needs analysis is not restrained to ESP courses; its consideration is observed in different educational program improvement and surveys.

According to Strevens (1980), ESP is derived from communicative language educating, and it is formulated to address specific learners' issues as well as themes and subjects related to the occupations or the study areas. Hence, ESP is arranged to advance the abilities of students to empower them in communicating in the English language (Tarnopolsky, 2009). Alternatively, Amirian and Tavakoli (2009) claimed that the great establishment on which ESP arose was the variety and particularity of students' aims and needs for learning English. Belcher (2004) stated that ESP is an endeavor for assisting students with achieving their scholastic and occupational requirements and objectives, so students' necessities should be deliberately evaluated by a needs assessment.

Furthermore, it is believed that students in ESP classes often have limited time to learn English, so it is rational to teach them just the pre-specified sections of English in line with their needs. As a result, in terms of syllabus design and course development, it is the responsibility of the ESP course designer to identify and classify the needs of the learners and design the particular course based on these needs (Basturkmen, 2010).

EAP has gained popularity because of the great number of international learners learning in British and American colleges (Hyland, 2006). Accordingly, these colleges intended to set EAP courses to improve the learners' scholastic abilities in English to arrive at the standards needed for entering universities where English is considered as the educating language. Given the significance of EAP syllabuses in Iran as the principal part of the ELT curriculum with evident instructive and monetary investments, course planners ought to reconsider the necessities of learners to build up their current status.

Having been agreed as the significant advance in planning an EAP course, the significance of needs assessment is featured in research when arranging courses, coordinating reading material, and deciding the type of educating and learning that will continue (Dudley_Evans \& St John, 2001; Long, 2005). Needs analysis is considered as a criterion when course design is concerned due to the variety of needs and their distinctive and situation-based nature (Amirian and Tavakoli, 2009).

Conventionally, learners act as the central source of information in needs analysis literature. Learners can be an effective source of information; nevertheless, this is not certainly so, as in many circumstances' learners do not know what their real language needs are. Numerous researchers such as Robinson (1991), Brown (2009), Seedhouse (1995), Graves (1999), Richards (2001), and Long (2005), approve that in ESP course design, needs analysis plays a significant 
role. Therefore, it is a vital trait of ESP and thus the EAP course plan to the extent that Belcher (2009) referenced that needs assessment ought to be considered as something educators can regard as a piece of their instructing.

Moreover, needs analysis is the development of defining the needs for which a learner or number of learners necessitate a language and placing the needs along with significances in language teaching and language program design. Needs assessment makes use of both subjective and objective needs, as a result, needs analysis has become an essential component of the field ESP as the foundation for designing ESP course (Johns and Dudley-Evans, 1991).

On the other hand, Maleki and Zangani (2007) stated that one of the most serious difficulties that EFL students in Iran face in their field of study after graduating from university is their incapability in communicating and handling English. This is as a result of their weaknesses in English, which affect their academic accomplishment. These refer to the importance of EAP courses, which prepare university students to use English for their academic objectives.

While traditional approaches to NA usually integrate linguistic units of analysis, there has appeared as a different approach, using task as the unit of needs analysis. In the same vein, Long (2005) supports task as a possible unit of analysis in NA on some grounds, most basically an SLA-motivated basis which he provides for the implementation of an analytic syllabus generally, and particularly for task-based language teaching.

In fact, tasks in task-based language teaching are regarded as the systematic unit of the syllabus and arrange a course around various types of tasks (Long, 2005). Principles underlying TBLT also put more emphasis on the importance of developing pedagogic tasks based on authentic tasks, which learners must achieve through the target language after or all through the course. Consequently, to improve a TBLT program, conducting a task-based needs analysis for classifying real-world target tasks and developing pedagogic tasks based on them seems to be very required. Task-based needs analysis is supposed to increase the real-world significance of the course and to improve EAP learners' interest. Indeed, task-based learning in teaching ESP can be extensively applied at the university level (Kavaliauskienk, 2005). However, the area of learners' preferences in employing tasks remains unexplored. This research attempts to consider the issue, which might help language practitioners, develop their everyday teaching activities based on the learners' needs.

\section{REVIEW OF LITERATURE}

\section{A. Historical Background EAP}

According to Hutchinson and Waters (1987), there are several reasons for the existence of English for specific purposes (ESP). First, Ibrahim (2017) stated that after the end of the Second World War, enormous development happened in technology, science, and economics. A foreign language was crucial since such growth was international. Due to the economic states of the United States, the English language ended up being its official language. Another reason was due to the results of linguistic research on language use. It has been proved that peoples' use of language when speaking and writing are significantly different depending on the situation. The findings have left an impact on English teaching. Moreover, students have varying expertise. Hence, it is common for them to use or require a language that changes from one field to another. The third reason for ESP development is the advancement in educational psychology. When one emphasizes the learner, it is brought to light that learners have different needs that can affect their ambition. "Paramount" is a language course that meets learners' needs and attends to their concerns.

\section{B. What Is EAP?}

English for academic purposes (EAP) has emerged from the widespread field of English for specific purposes (ESP) and is characterized by focusing on instructing English specially to make students' studying or research in English easier (Flowerdew \& Peacock, 2001, Hyland \& Hamp-Lyons, 2002). EAP is segregated from ESP by focusing on scholarly settings; however, the perspective on EAP as a sub-discipline toward ESP actually endures among the applied linguistics and English language teaching fields. EAP is the linguistic, sociolinguistic, and psycholinguistic portrayal of English when it occurs with regards to scholastic study as well as academic exchange (Hyland \& Hamp-Lyons, 2002).

\section{Definition and Importance of Needs Analysis (NA)}

The differences between the two types of needs are reported by Hutchinson and Waters (1987). The first is known as the target needs; in other words, the students' needs in the target circumstance. Indeed, there are three classifications for target needs: "necessities", which alludes to what students need to have in the target state; "lacks", referring to the difference between the information that students have and what is required in the target state; "wants", alluding to what students believe that they require. Hutchinson and Waters proposed learning needs as the second type of needs. This type of needs considers how learners learn. Moreover, it takes account of information about learners, objectives for learning the language, and the ESP course time and situation (Hutchinson \& Waters, 1987).

Needs analysis is an essential stage in course design, so it is widely repeated in the literature (Brown, 1995; Bachman and Palmer, 1996; Kumaravadivelu, 2006; Tomlinson, 2016). Needs analysis regards the process in which researchers collect, analyze, and assess different information sources to provide the unique needs of ESP learners (Gea-Valor, ReyRocha, and Moreno, 2014; Huhta, Vogt, Johnson, and Tulkki, 2013). At the center of the ESP course development (Serafini, Lake, and Long, 2015), the first stage in the development of the ESP course which is organized to determine the content and methodology of a course is NA (Flowerdew, 2013). 
As Basturkmen, (2013) and Long (2015) stated, the importance of NA as a key stage in course design is greatly acknowledged in the literature. For instance, Richards (2001) revealed that NA significantly gave a solid and legitimate reason for defining aims and objectives, improving syllabuses and teaching contents, alongside assessment and redevelopment of projects. Needs analysis is fundamental to an EAP approach in course design. Furthermore, at Iranian universities, there are recently some needs analysis projects which tried to assess the needs of students (Hamp-Lyons, 2001). For example, a needs analysis study is conducted to explore students' reading challenges as an initial step in designing a suitable reading intervention program for students of first-year sociology (Boakye and Mai, 2016).

Mackay and Mountford (1978, cited in Muhammad Nadzri, 2004) declared four primary purposes of resuming the roles of needs analysis in language curriculum design. First, lecturers will be more aware of the sponsoring institution and the course requirements. Second, needs assessment recognizes how students will utilize English in their specialized fields. Moreover, it gives the educator fundamental knowledge of the prospective learners' present level of performance in English. Additionally, it provides the opportunity to collect samples of original texts, both spoken and written, that can be used in the target situation. Ultimately, needs analysis helps instructors translate the language needs into pedagogical and linguistic terms that orderly build a suitable curriculum for courses and proposes practical guidance for instructors teaching the courses. Muhammad Nadzri (2004) proclaimed that the aforementioned four significant justifications produced evidence that needs analysis is without a doubt regarded as a crucial component of the language curriculum development, specifically in EAP.

\section{Needs Analysis in EAP}

All curriculum design for EAP courses needs to consider the different language needs of the target learners. Indeed, a strong foundation connected to the whole idea of conducting particular language courses is formed by determining the language needs of learners. The entire process of designing the curriculum, from the course objectives construction to the course contents selection and learning activities, is made more accessible by that preliminary knowledge. This might present a guarantee in the quality of the courses, particularly in helping the learners to achieve the expected learning outcomes. A needs analysis must be carried out for starting information collection on the learners' language needs.

All the ESP and EAP researchers and practitioners share a similar notion in simplifying what "needs analysis" is. Needs analysis is a mere tool that evaluates different kinds of English and literacy skills needed by learners. At the same time, it identifies the literacy contexts of the target language and what learners want and need to know in order to execute in those contexts, as well as what they await to attain from the educational program (Duzer \& Weddel, 1997). As well as the identification of the linguistic items needs analysis will explore what the learners should do to apply those items and how those items will be used in the predicted context. Needs analysis refers to the activities that take place when gathering data that indicate the basis of curriculum development that achieves the learning necessities of a specific student group (Brown, 1995).

Wei and Flaitz (2005), regarding what should be focused on needs analysis, recognized it as something subjective when learners' needs can be examined in several skills or only a specific skill. Likewise, they saw that researchers gather information to be comfortable with the assignments that learners will encounter in college classes and furthermore scrutinize the abilities the learners needed to carry out those assignments successfully. The recent focus is involving the student learning styles and strategies, which Kavaliauskiene and Uzpaliene (2003) seen as an essential aspect in needs analysis. Therefore, Mo (2005) viewed needs analysis as the process of establishing what and how of a language course.

Accordingly, since the quality of learning may be questioned, using this short-cut approach for deciding the course syllable poses a threat to both instructors and students. Hence, a little effort needs to be applied to perform needs analysis so all doubts belonging to the quality of the curriculum might be avoided in developing curriculum for any language courses.

\section{Approaches to NA}

To study needs analysis, numerous approaches can be identified (Ali, 2011; Kaewpet, 2009; Songhori, 2008). Target situation analysis (TSA) and present situation analysis (PSA), which are basic elements in studying students' language learning needs, are proposed by Ali (2011).

\section{Target Situation Analysis (TSA)}

According to Songhori (2008), Chambers in 1980 used TSA as he attempted to clarify the terminology confusion. The latter refers to TSA as "communication in the target situation." Mumbay (1978) applied this model when he introduced his Communicative Needs Processor (CNP) in 1978 (Songhori, 2008; Kaewpet, 2009). The CNP signified the development of ESP (Hutchinson \& Waters, 1987). The machine required for studying any groups of learners' needs had been supplied, and course designers needed but to make use of it. TSA refers to the term that includes necessities, lacks, and wants (Hutchinson \& Waters, 1987). TSA depends on posing inquiries about the target state and the members' mentalities toward that circumstance. Six primary questions are included in TSA, which are subsequently divided into several different inquiries. The primary questions consider the goals for which the language is required, the way the language is utilized, the content zones, who are associated with the interaction procedure, the circumstance wherein the language will be utilized, and when the language will be utilized (Hutchinson \& Waters, 1987). Robinson (1991) considers TSA as attention on what learners require toward the course's end. Dudley-Evans and St John (1998) and Hyland (2006) express that TSA involves factual, comprehended, and product-oriented necessities. 


\section{Present Situation Analysis (PSA)}

Another NA approach is PSA, which could be viewed as TSA's supplement (West, 1997). Indeed, TSA intends to recognize what students are capable of doing after the course while PSA plans to start how students are toward the start of the course. In addition, PSA shows the "weakness and strength in language, skills, and learning experience" (DudleyEvans \& St John, 1998), and PSA, consequently, gives the beginning stage of the course. As asserted by Songhori (2008), Richterich and Chancerel presented PSA in the 1980s that satisfies numerous purposes by creating information using different sources. For example, it obtains data from students, the professional establishment, and the educational organization. Also, placement tests may be carried out as a source of data to identify the teachers' current state in the language. However, information about learners' years of learning English experience and educational level can provide necessary data about their talents and abilities.

As stated by Robinson (1991), needs analysis should be regarded as a combination of both TSA and PSA. Moreover, Hyland (2006) recommends that PSA make both objective and subjective information available. Therefore, PSA alludes to recognizing learners' current degree of capability including deficiencies whereas TSA attempts to distinguish what learners need to do in the target state.

\section{Task-based Language Teaching}

TBLT method in language education offers learners chances to be associated with the genuine utilization of the target language through assignments. The assignment is the principle segment in TBLT, which prepares the primary context, which also elevates language utilization like how language is applied outside the class. Ellis (2003) stated that students could learn the language and improve skills when they work into completing the task that motivates them to enhance their available language resources. According to Samuda and Bygate (2008), there are different definitions of a task in the literature as a result of varying perspectives and purposes of researchers and teacher educators studying tasks and TBLT.

The TBLT benefits have been competently explained in the literature as Nunan (2004) emphasized using the language for authentic purposes and believed TBLT is important on the grounds that students can study the language through communicating mutually and taking part in significant tasks. He additionally viewed TBLT as proper for learners' requirements and interests, as it enhances language learning and the development of important skills for finishing tasks that learners encounter outside the class. Moreover, these advantages are emphasized by referencing that learners utilize self-chosen language during assignments that assist them with focusing on the meaning of their message to finish it (Ellis 2003b, 2009). Specific language items are not introduced for students, so they are free of language control. Students apply the language that they have instead of practicing specified language items.

Task-based language teaching is a student-centered approach to teaching along with being adaptable (Van den Branden, 2012). Students communicate naturally in situations that they experience outside of the classroom with the language, which is highly connected to them. Task-based language teaching considers tasks as the logical unit of the syllabus and arranges a course around different types of tasks (Long, 2005; Long and Crookes, 1992). In addition, the principles of TBLT put more emphasis on the importance of developing academic tasks based on authentic tasks, which learners should perform through the target language after or during the course. Thus, it is essential to manage a taskbased NA for recognizing real-world target tasks and improve pedagogic tasks based on them to develop a TBLT program. Task-based NA can increase the real-world purpose of the course and enhance the motivation and interest of learners.

In accordance with Long (2005), task-based needs analysis is more advantageous than other traditional needs analysis approaches, like the learning-centered approach (Hutchinson and Waters, 1994), present situation analysis (Richterich and Chancerel, 1980), and target situation analysis (Munby, 1978) since it can prepare more valid data about the target tasks, it can identify the authentic uses of the language, and its outcomes can be easily used just as input for the content-based or task-based course design.

A few investigations have been completed in this domain. Liu, Chang, Yang, and Sun (2011) investigated English as a foreign language that university learners require in English for General Purposes (EGP) and English for ESP/EAP courses regarding their impression of three subsegments of needs - necessities, wants and lacks. Moreover, there were contrasts between what learners perceived to need and the courses that they actually took, which emphasize the importance of acknowledging needs as a perplexing, numerous, and conflicting notion. The findings of the study propose that participants were in the wake of learning the English language so they could distribute their works and land regular positions as instructors. The educators engaged in expanding oral and listening abilities and utilizing English in the classes they taught.

Bouabdallah (2015) has studied the requirements of first-year master's scholars in biology at the University of Tlemcen, Algeria. The findings of the research affirmed that learners regarded speaking, listening, and translations from English to Arabic as primary abilities. Learners must comprehend lectures that are given in English, study and translate scientific papers, and take an interest in conversations. Also, the participants were inadept in English. The hardest skills for them to attain appeared to be writing and speaking in particular.

Furthermore, the language needs of tourism management graduates in Iran have been examined (Moattarian \&Tahririan, 2014). According to the study, all four skills were considered significant and tourism students laid 
emphasis on them. Students lacked the ability to communicate in English. Even though all the participants confirmed the importance of English in this field, graduates revealed that they found the previous ESP course ineffective.

\section{DISCUSSION AND CONCLUSION}

EAP courses are predominantly intended to support non-native students to deal with the demands at English-medium universities and to improve academic literacy and study skills and nowadays these types of courses aim at assisting language learners to study, carry out research or teach in English (Flowerdew and Peacock, 2001). Furthermore, the purpose of EAP courses is to help learners to learn some of the linguistic and cultural practices take in studying or working in such a setting (Gillett, 2011). As a result, EAP is beginning with the learner and the situation and not with the language itself as in English for General Purposes (Hamp-Lyons, 2001).

As in any other EFL course, the instructor can select an applied methodology for an EAP course consistent with the teaching philosophy, the specific needs of the students, and the demands or procedures of the particular association. Nevertheless, as it is apparent from the study of Douglas and Kim (2014), examining EAP classes, task-supported teaching is widespread and supposed to be highly advantageous.

As EAP has very accurate structures, clearly discriminating it from English for General Purposes, the selected teaching methodology has to be intended to cover these issues efficiently, chiefly concerning the very partial existing time in pre-courses. Hence, it has been recommended that the numerous advantages of TBLT, for example, its comprehensive way to deal with language and its involvement in language, alongside its emphasis on real-life assignments, can help international students manage the increased requests of an English-medium university, both on a linguistic and a scholastic level.

The students are provided with opportunities to employ TBLT structures to put emphasis first on making meaning, and then on usage; nevertheless, not ignoring it. Maybe, the advantage of this approach is the fact that students can have a priori knowledge by the reliable element of TBLT during the research, transfer this knowledge, and developed skills to their conventional research.

When planning a TBLT lesson, choosing suitable assignments is of utmost importance. According to Benesch (1996), when doing so for EAP courses, the particular needs of students must first be recognized and then taken into effective consideration. These needs depend on their major, level of language proficiency, cognitive level, and cultural background. As a matter of fact, Gillett (2011) asserted that in order to get involved in the courses, students will be requiring linguistic assignments constituting both language and practices.

However, the TBLT approach has a few difficulties that need to be overcome. For example, language teachers may not be familiar with it and may need additional preparation for it. Moreover, it is normally them who have to plan the assignments or adjust the current teaching material to TBLT, which requires specialized information, thereby being time-consuming. Furthermore, educators need to discover the harmony between the focus on the significance and on the structure, which should be achieved when grading learners who are given a task.

Choosing an appropriate task topic is significant as well. As declared by Willis (1996), the topics must be chosen in such a manner that they motivate students, grasp their attention, provide a suitable level of intellectual and linguistic challenge, and enhance their language progress. Moreover, TBLT has not been created to help the goals of examoriented courses and to prepare students for specific standardized high-stake types of English language exams. Therefore, it is suggested that TBLT is ideal for an EAP setting, where the last evaluation can be of an alternate sort.

Indeed, even though most researchers have accentuated the significance of EAP's needs analysis, little has been mentioned on the needs' type and quantity. The examinations on the language assignments' role and significance in EAP lack in giving proof of the sources of assignments, which can give the vital requirements to EAP in the EFL setting.

\section{REFERENCES}

[1] Ali, A. A. (2011). A needs analysis for designing an ESP syllabus for the students of Sudan Naval Academy (Doctoral dissertation). Al Neelain University, Khartoum, Sudan.

[2] Alqahtani, M. (2011). An investigation into the language needs of Saudi students studying in British postgraduate programmes and the cultural differences impacting on them (Unpublished doctoral dissertation). University of Southampton, Southampton, UK.

[3] Amirian, Z., \& Tavakoli, M. (2009). Reassessing the ESP courses offered to engineering students in Iran. English for specific purposes world. 8 (23), 1-13.

[4] Bachman, L. F., \& Palmer, A. S. (1996). Language testing in practice: Designing and developing useful language tests .Oxford: Oxford University Press.

[5] Basturkmen, H. (2010). Developing Courses in English for Specific Purposes. University of Auckland, New Zealand. Palgrave Macmillan. New York.

[6] Basturkmen, H. L. (2013). Needs analysis and syllabus design for LSP. In C. A. Chapelle (Ed.), The encyclopedia of applied linguistics (pp. 4209-4217). West Sussex: Wiley- Blackwell.

[7] Bedoya, P. A., Valencia, L. M., \& Montoya, J. C. (2015). Students' needs analysis in an EFL programme for university professors. HOW, 22(2), 11-36. Retrieved on August 2020 from https://doi.org/10.19183/ how.22.2.118. 
[8] Belcher, D. (2009). What ESP is and can be? An introduction. In D. Belcher (Ed.), English for specific purposes in theory and practice (pp. 1-20). Ann Arbor, US: University of Michigan Press. Retrieved on August 2020 from https:// doi.org/10.3998/mpub.770237.

[9] Belcher, D. D. (2004). Trends in teaching English for specific purposes. Annual review of applied linguistics, 24 (2), $165-186$.

[10] Benesch S. (1996). Needs analysis and curriculum development in EAP: an example of a critical approach. TESOL Quarterly, 30 (4), 723738.

[11] Boakye, N. A. N. Y., \& Mai, M. M. (2016). A needs analysis for a discipline specific reading intervention. English Language Teaching, 9(3), 235-247.

[12] Bouabdallah, F. H. (2015). A course design in ESP: The case of Master's students in the Department of Biology, University of Tlemcen (Master's thesis). University of Tlemcen, Algeria.

[13] Brown, J. D. (1995). The elements of language curriculum. Boston: Heinle \& Heinle.

[14] Brown, J. D. (2009). Foreign and second language needs analysis. In M. H. Long \& C. J. Doughty (Eds.), The handbook of language teaching (pp. 269-293). London, UK: Wiley-Blackwell. Retrieved on August 2020 from https:// doi.org/10.1002/9781444315783.ch16.

[15] Douglas, S. (2014). Teacher perceptions of task-based language teaching and learning across Canada. Contact: Special Research Symposium Issue, 40(2), 11-31. Retrieved on July 2020 from http:// www.teslontario.net/publication/researchsymposium.

[16] Dudley-Evans, T., \& St John, M. (1998). Developments in English for specific purposes. Cambridge: Cambridge University Press.

[17] Dudley-Evans, T., \& St John, M. (2001). English for specific purposes. In R. Carter, \& D. Nunan, (Eds.). The Cambridge guide to teaching English to speakers of other languages (pp. 131-136). Cambridge: Cambridge University Press.

[18] Ellis, R. (2003a). Designing a task-based syllabus. RELC Journal, 34(1), 64-81.

[19] Ellis, R. (2003b). Task-based language learning and teaching. Oxford, UK: Oxford University Press.

[20] Ellis, R. (2009). Task-based language teaching: Sorting out the misunderstandings. International Journal of Applied Linguistics, 19(3), 221-246.

[21] Flowerdew, J., \& Peacock, M. (2001). Issues in EAP: A preliminary perspective. In J. Flowerdew \& M. Peacock, (Eds.), Research perspectives on English for Academic Purposes (pp. 8-24). Cambridge: Cambridge University Press.

[22] Flowerdew, L. (2013). Needs analysis and curriculum development in ESP. In B. Paltridge \& S. Starfield (Eds.), The Handbook of English for specific purposes (pp. 325-347). West Sussex: Wiley-Blackwell.

[23] Gea-Valor, M-L., Rey-Rocha, J., \& Moreno, A. L. (2014). Publishing research in the international context: An analysis of Spanish scholars' academic writing needs in the social sciences. English for Specific Purposes, 36(1), 47-59.

[24] Gillett, A.J. (2011). What is EAP? Retrieved on August 2020 from http://www.uefap.com/bgnd/.

[25] Graves, C. (1999). Designing language courses: A guide for teachers. Boston, UK: Heinle \& Heinle.

[26] Grunert O’Brien, J., Millis, B. J., \& Cohen, M. W. (2008). The Course Syllabus, A Learning-Centered Approach (2 ${ }^{\text {nd }}$ ed.). San Francisco: Jossey-Bass.

[27] Hamp-Lyons, L. (2001). English for Academic Purposes. In R. Cater \& D. Nunan (Eds.), The Cambridge guide to teaching English to speakers of other languages (pp.121-130). Cambridge: Cambridge University Press.

[28] Huhta, M., Vogt, K., Johnson, E., \& Tulkki, K. (2013). Needs analysis for language course design: A holistic approach to ESP. Cambridge: Cambridge University Press.

[29] Hutchinson, T., \& Waters, A. (1987). English for specific purposes: A learning centered approach. Cambridge, UK: Cambridge University Press.

[30] Hyland, K. (2006). English for academic purposes: An advanced resource book. London, UK: Routledge.

[31] Hyland, K., \& Hamp-Lyons, L. (2002). EAP: Issues and directions. Journal of English for Academic Purposes, 1(1), 1-12.

[32] Ibrahim, A. M. (2017). Specialization professors' perception on their students' needs for ESP: PEH students' case. English for Specific Purposes World, 54(19), 1-22.

[33] Johns, A., \& Dudley-Evans, T. (1991). English for specific purposes: International in scope, specific in purpose. TESOL Quarterly, 25(2), 297- 314.

[34] Kaewpet, C. (2009). Communication needs of Thai civil engineering students. English for Specific Purposes, 28(4), $266-278$.

[35] Kavaliauskiene, G. ,\& Uzpaliene, D. (2003). Ongoing needs analysis as a factor to successful language learning. Journal of Language and Learning, 1(1), 35-50.

[36] Kavaliauskienk, G. (2005). Task-based learning and learning outcomes in the ESP classroom. Studies about Languages, 7 (2), $1-6$.

[37] Kumaravadivelu, B. (2006). Understanding language teaching: From method to postmethod. New York: Routledge.

[38] Liu, J. Y., \& Chang, Y. J., \& Yang, F. Y., \& Sun, Y. C. (2011). Is what I need what I want? Reconceptualizing collage students' needs in English courses for general and specific/academic purposes. Journal of English for Academic Purposes, 10(4), 271280.

[39] Long, M. H. (2005). Second language needs analysis. Cambridge: Cambridge University Press.

[40] Long, M. H. (2015). Analyzing target discourse. In M. H. Long (Ed.), Second language acquisition and task-based language teaching (pp. 169-204). Oxford: Wiley-Blackwell.

[41] Long, M. H., \& Crookes, G. (1992). Three approaches to task-based syllabus design. TESOL Quarterly, 26(1), 27-56.

[42] Maleki, A., \& Zangani, E. (2007). A survey on the relationship between English language proficiency and the academic achievement of Iranian EFL students. Asian EFL Journal, 9(1), 86-96.

[43] Mo, H. (2005). A brief review of English for academic purposes (EAP). US-China Foreign Language, 3(7), 62-67.

[44] Moattarian, A. M., \& Tahririan, M. H. (2014). Language needs of graduate students and ESP courses: The case of tourism management in Iran. Journal of Research in Applied Linguistics, 5(2), 4-22. Retrieved on July 2020 from http://rals.scu.ac.ir/article_11009_1201.html. 
[45] Muhammad Nadzri A .A. (2004). Needs analysis of Malaysian higher national diploma students. Unpublished master's dissertation, University of Malaya, Kuala Lumpur. needs analysis. Proceedings of the $3^{\text {rd }}$ Annual JALT Pan-SIG Conference, Tokyo: Tokyo Keizai University.

[46] Munby, J. (1978). Communicative syllabus design. Cambridge: Cambridge University Press.

[47] Nunan, D. (2004). Task-based language teaching. Cambridge: Cambridge University Press.

[48] Richards, J. C. (2001). Curriculum design in language teaching. New York, NY: Cambridge University Press.

[49] Richterich, R., \& Chancerel, J.L. (1980). Identifying the needs of adults learning a foreign language. Oxford: Pergamon Press.

[50] Robinson., P.C. (1991). ESP today: A practitioner's guide. London: Prentice Hall.

[51] Samuda, V., \& Bygate, M. (2008). Tasks in second language learning. New York, NY: Palgrave Macmillan.

[52] Seedhouse, P. (1995). Needs analysis and the general English classroom. ELT Journal, 49(1), 59-65. Retrieved on July 2020 from https://doi.org/10.1093/elt/49.1.59.

[53] Serafini, E. J., Lake, J. B., \& Long, M. H. (2015). Needs analysis for specialized learner populations: Essential methodological improvements. English for Specific Purposes, 40(3), 11-26.

[54] Shing, S., \& Sim, T. (2011). EAP needs analysis in higher education: Significance and future direction. English for specific purposes world, 33(11), 1-11.

[55] Songhori, M. H. (2008). Introduction to needs analysis. English for Specific Purposes World, 4(20), 1-25.

[56] Strevens, P. (1980). Teaching English as an international language: from practice to principle. Oxford: Pergamon.

[57] Tarnopolsky, O. (2009). Content-based internet-assisted ESP teaching to Ukrainian University students majoring in psychology. The Reading Matrix, 9 (2), 184-197.

[58] Tomlinson, B. (2016). The importance of materials development for language learning, Issues in Materials Development for language learning. In: Azarnoosh, M., Zeraatpishe, M., Favarani, A. \& Kargozari, H (eds.) Issues in Materials Development (pp. 1-9). Rotterdam: Sense Publishers.

[59] Van den Branden, K. (2012). Task-based language education. In A. Burns \& J. C. Richards (Eds.), The Cambridge guide to pedagogy and practice in second language teaching (pp. 132-139). Cambridge, UK: Cambridge University Press.

[60] Wei, Z., \& Flaitz, J. (2005). Using focus group methodology to understand international students' ${ }^{\text {'ee }}$ academic language needs: A comparison of perspectives. TESL-EJ, 8(4), 1-11. Retrieved on August 2020 from http://writing.berkeley.edu/TESLEJ/ej32/a3.html.

[61] West, R. (1997). Needs analysis: State of the art. In R. Howard \& G. Brown (Eds.), Teacher education for languages for specific purposes (pp. 68-97). London, UK: Multilingual Matters.

[62] Willis, J. (1996). A framework for task-based learning. Harlow, UK: Addison Wesley Longman.

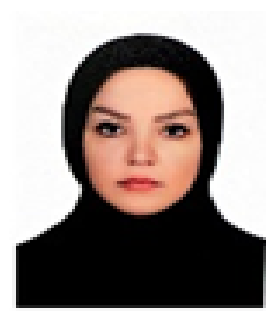

Maryam Cheraghi Shehni is a Ph.D candidate of Applied Linguistics at Department of Language Teaching and Translation Studies at Islamic Azad University. She is currently an English Language teacher. Her current research interests include Teacher education, Reading, CALL, ESP and Reflective teaching. 